Mathews, J. D., and Mackay, I. R. (1970). British Medical fournal, 1, 259.

Meyer zum Büschenfelde, K. H., Kössling, F. K., and Dietz, R. (1969) Verhandlungen der Deutschen Gesellschaft für Pathologie, 53, 325. Paronetto, F., Schaffner, F., and Popper, H. (1961). Proceedings of the Society for Experimental Biology and Medicine, 106, 216.

Preisig, R. Gocke, D., Morris, T., and Bradley, S. E. (1966). Experientia, 22, 701.

Prince, A. M. (1968a). Proceedings of the National Academy of Sciences, 60, 814.

Prince, A. M. (1968b). Lancet, 2, 462.
Rubin, E., Schaffner, F., and Popper, H. (1965). American fournal of Pathology, 46, 387.

Vischer, T. (1969). Médicine et Hygiène, 27, 1003.

Walker, J. G., Doniach, D., Roitt, I. M., and Sherlock, S. (1965). Lancet, 1,827 .

Wright, R., McCollum, R. W., and Klatskin, G. (1969a), Lancet, 2, 117.

Wright, R., McCollum, R. W., and Klatskin, G. (1969b.) Gut, 10, 1052 Abstract.

Zuckerman, A. J., Taylor, P. E., and Almeida, J. D. (1970). British Medical fournal, 1, 262.

\title{
Enzyme Activity, Acidic Nuclear Proteins, and Prognosis in Human Breast Cancer
}

\author{
J. A. SMITH, ${ }^{*}$ M.sc. ; R. J. B. KING, ${ }^{*}$ PH.D. ; B. F. MEGGITT,† F.R.c.s. ; L. N. ALLEN, $\ddagger$ F.R.c.s.
}

British Medical fournal, 1970, 2, 698-701

\begin{abstract}
ummary: The activities of the enzymes lactate dehydrogenase, 6-phosphogluconate dehydrogenase, and phosphohexose isomerase in primary human breast cancer biopsies are shown to be related to the time between mastectomy and recurrence of the cancer. These enzymes have higher activity in malignant breast tissues generally than in non-malignant breast tissues. In tumours from patients with long free periods these differences are not apparent.
\end{abstract}

Evidence is presented which suggests that two different types of breast cancer can be distinguished according to the relative amounts of phosphohexose isomerase and acidic nuclear proteins. It is suggested that this difference may be related to hormone responsiveness.

\section{Introduction}

We have previously described some biochemical differences between human mammary tumours and non-malignant mammary tissue (Smith, King, Meggitt, and Allen, 1966). The activities of the enzymes $\beta$-glucuronidase, phosphohexose isomerase, lactate dehydrogenase, isocitrate dehydrogenase, glucose-6-phosphate dehydrogenase (G-6-PD), and 6phosphogluconate dehydrogenase (6-PGD) were measured. These enzymes were chosen because there is a considerable body of evidence that neoplastic tissues differ from normal tissues in carbohydrate metabolism (Aisenberg, 1961). There is also evidence that some of these enzymes may be correlated with important clinical characteristics in animal tumours, such as growth rate (Shonk, Morris, and Boxer, 1965) or hormone responsiveness (Rees and Huggins, 1960).

In our study the enzyme activities in the tumours were very variable, but the activities of several pairs of enzymes were correlated-for example, lactate dehydrogenase and 6PGD; phosphohexose isomerase and G-6-PD. We concluded that, despite the high variability of the individual enzyme activities, the enzyme pattern - that is the relative activities of the enzymes to each other-had a certain constancy, and suggested that quantitative differences in enzyme activity patterns might be of some prognostic value. The acidic nuclearprotein content of the tumours was also measured, since there was evidence that the amount of these proteins was correlated with growth rate. This work has been extended, and the present paper is an attempt to assess the clinical significance of the results in the light of postoperative "follow-up" information.

\footnotetext{
*Department of Hormone Biochemistry, Imperial Cancer Research Fund, London W.C.2.

†Surgical Registrar, Royal National Orthopaedic Hospital, Stanmore, Middlesex.

$\ddagger$ Consultant Surgeon, Edgware General Hospital, Edgware, Nijdlesex.
}

\section{Materials and Methods}

Tissue samples were obtained within 10 to 15 minutes of excision. All the malignant tumours were primary breast carcinomata. Non-malignant tissue was obtained from uninvolved areas of breast containing carcinoma or from patients with cystic glandular hyperplasia. The clinical diagnosis was confirmed by histological examination of the samples. Tissues were frozen on solid $\mathrm{CO}_{2}$ and stored at $-20^{\circ} \mathrm{C}$. until used. The variables measured were not significantly altered after as long as six months' storage under these conditions. We have no evidence for the effect of the initial freezing on human tissues, but in rat liver and in mouse tumours the variables were unaffected by this treatment and remained stable thereafter for long periods at $-20^{\circ} \mathrm{C}$. (Shonk and Boxer, 1964, and personal observations). Analyses were generally performed within one month of excision.

Assay Methods.-These have been described in detail (Smith et al., 1966). The assays were performed in three stages, each requiring a separate homogenization.

D.N.A., R.N.A., Total Protein, Phosphohexose Isomerase, and $\beta$-glucuronidase.-Slices (about $200 \mathrm{mg}$.) were cut from the frozen tissue and homogenized with a Silverson homogenizer (Silverson Machines Ltd., London) in $1.8 \mathrm{ml}$. of a solution containing $\mathrm{KCl}(0.15 \mathrm{M}), \mathrm{NaHCO}_{3}(0.003 \mathrm{M})$ and edetic acid $(0.006 \mathrm{M}), \mathrm{pH}$ 6.7. Portions of this homogenate were used to estimate D.N.A. (Burton, 1956) and total protein (Lowry, Rosebrough, Farr, and Randall, 1951). Phosphohexose isomerase activity was determined by measuring the amount of fructose-6-phosphate formed from glucose (Bodansky, 1954) after 10 minutes' incubation of enzyme and substrate at $37^{\circ} \mathrm{C}$. in tris buffer $(0.025 \mathrm{M} \mathrm{pH} \mathrm{7.4).} \beta$-glucuronidase was measured, phenolphthalein $\beta$-glucuronide being used as substrate. The assay conditions were taken from the Sigma Chemical Co. (St. Louis, U.S.A.) Bulletin 105 (1951). Triton X-100 was added to the incubation mixture at a final concentration of $0.002 \%(\mathrm{v} / \mathrm{v})$ to release any bound enzyme. Assay conditions for both these enzymes were chosen to give linear reaction rates over the period of incubation.

Dehydrogenases (Lactate Dehydrogenase, Isocitrate Dehydrogenase, G-6-PD, 6-PGD).-A second homogenate was prepared, as above, and centrifuged at $2,000 \mathrm{~g}$ for 30 minutes at $40^{\circ} \mathrm{C}$. The supernatant was kept on ice until used. The enzyme activities were measured by recording the rates of change in absorbance at $340 \mathrm{~m} \mu$ due to the oxidation or reduction of the appropriate nicotinamide adenine dinucleotide with a Unicam SP 700 recording spectrophotometer. The conditions were chosen to give maximal rates at $p H$ 7.4. In all cases the measurements are based on zero-order activity? curves. Details of the reaction mixtures used were given in a previous publication (Smith et al., 1966).

Acidic Nuclear Proteins.-Frozen tissue (100-200 mg.) was homogenized in $3 \mathrm{ml}$. of ice-cold $0.25 \mathrm{M}$ sucrose : $3 \mathrm{mM} \mathrm{CaCl}$ 
and filtered through a wire gauze. Nuclei were isolated by sucrose density gradient centrifugation (Allfrey, Littau, and Mirksy, 1964) and acidic nuclear protein prepared as described previously (Smith et al., 1966).

Expression of Results.-Enzyme activities were expressed in international units (the amount of enzyme required to transform $1 \mu$ mole of substrate in one minute). Activities have been calculated per mg. D.N.A., since this seemed the most reasonable basis for comparing such histologically heterogeneous tissues.

\section{Results}

Of over 100 patients whose tumours have been analysed 25 are known to have had recurrences within a period of four years and 20 others have been followed for more than two years without recurrence. Eleven who were followed for more than three years showed no signs of recurrence. The time between mastectomy and recurrence is termed the "free period." The patients with free periods of more than three years had lower enzyme activities than those who had recurrences within three years of primary treatment (Table I). The differences were significant for 6-PGD $(\mathrm{P}<0.02)$ and lactate dehydrogenase $(P<0.01)$.

Similar differences were found when patients with free periods greater than two years were compared with those with shorter free periods. This suggested that enzyme activity in primary carcinoma might reflect the probable free period. The relationship of enzyme activity and free period is shown in Fig. 1. Several of the enzymes showed an inverse correlation with free period. This was particularly clear for phosphohexose isomerase, lactate dehydrogenase, and 6-PGD, which were significantly higher in tumours recurring within one year than in those with free periods of three years or more $(\mathrm{P}<0.02,0.05$, and 0.05 respectively). Most of the enzyme activities in tumours with the most favourable prognosis were indistinguishable from the activities in non-malignant breast tissue (Table I). $\beta$-glucuronidase was lower in tumours generally. In making these comparisons, data for non-malignant tissue from breasts with cystic glandular hyperplasia and those containing tumours have been combined where no significant difference was observed. The only significant difference between these two types of lissue was that cystic breast contained lower isocitrate dehydrogenase activity than uninvolved parts of tumour-containing breast $(P<0.01)$. In cystic breast the isocitrate dehydrogenase activity was also lower than in the tumours $(P<0.05)$.

The acidic nuclear protein content of the breast tumours paralleled the enzyme results in that poor prognosis was associated with high levels of these proteins (Fig. 2) but the differences were not significant.

\section{Possibility of Two Types of Tumour}

In a previous paper (Smith et al., 1966) we described a number of correlations between enzyme activities in breast

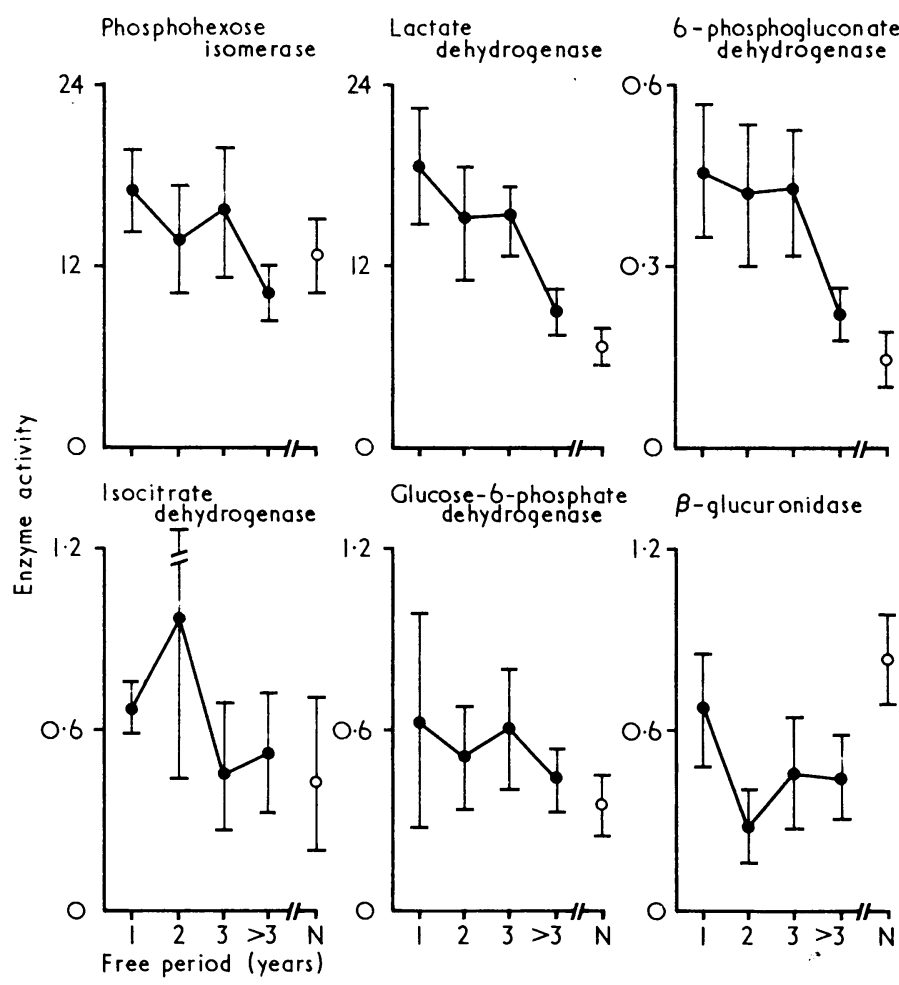

FIG. 1.-Relationship of enzyme activity and free period. Enzyme activities expressed per mg. D.N.A. Vertical bars represent S.E. of mean. $\mathrm{N}=$ Normal values.

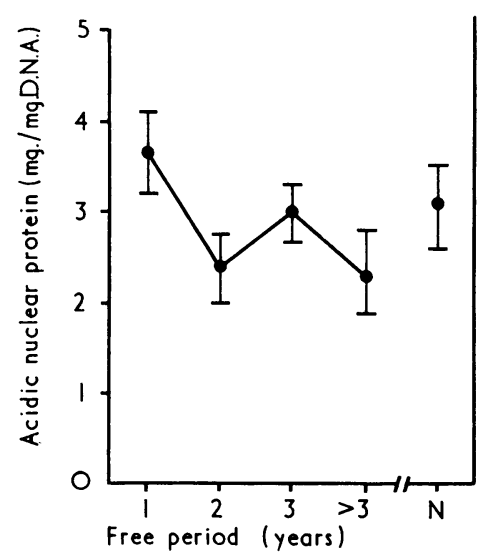

FIG. 2.-Relationship between acidic nuclear protein content per mg. D.N.A. and free period. Vertical bars represent S.E. of mean $N=$ Normal values.

tumours. The present results confirmed these findings, and in continuing this type of analysis we were struck by an apparent bimodal distribution of the ratio phosphohexose isomerase : acidic nuclear protein (Fig. 3). It appears that there are

TABle I.-Enzyme Activities and Acidic Nuclear Protein Content in Malignant Tumours from Patients with Recurrences within 3 Years of Mastectomy or Surviving mure than 3 Years without Recurrence, and Values for Non-malignant Breast Tissue. Expressed per mg. D.N.A. \pm S.E. of Mean. Number of Estimations in Parentheses

\begin{tabular}{|c|c|c|c|c|c|c|c|c|c|c|c|c|c|c|}
\hline & & & & & & & & & & & & $\begin{array}{l}\text { Patients with } \\
\text { Recurrence within } \\
3 \text { Years }\end{array}$ & $\begin{array}{l}\text { Patients Survived } \\
\text { more than } 3 \text { Years } \\
\text { without Recurrence }\end{array}$ & $\begin{array}{l}\text { Non-malignant } \\
\text { Breast Tissue }\end{array}$ \\
\hline $\begin{array}{l}\text { (S-glucuronidase (U.) } \\
\text { Phosphohexose isomerase (U.) } \\
\text { Lactate dehydrogenase (U.) } \\
\text { Isocitrate dehydrogenase (U.) }\end{array}$ & $\begin{array}{l}\cdots \\
\cdots \\
\cdots\end{array}$ & $\begin{array}{l}\cdots \\
\cdots \\
\cdots\end{array}$ & $\begin{array}{l}\cdots \\
\because \\
\cdots\end{array}$ & $\begin{array}{l}\cdots \\
\cdots \\
\cdots\end{array}$ & $\begin{array}{l}\cdots \\
\cdots \\
\cdots\end{array}$ & $\begin{array}{l}\cdots \\
\cdots \\
\cdots\end{array}$ & $\begin{array}{l}\cdots \\
\because \\
\cdots\end{array}$ & $\begin{array}{l}\cdots \\
\cdots \\
\cdots\end{array}$ & $\begin{array}{l}\cdots \\
\cdots \\
\cdots\end{array}$ & $\begin{array}{l}\cdots \\
\cdots \\
\cdots\end{array}$ & \begin{tabular}{l|l}
$\cdots$ & \\
$\cdots$ & \\
$\cdots$ &
\end{tabular} & $\begin{array}{l}0.049 \pm 0.008(20) \\
15 \cdot 5 \pm 2 \cdot 4(21) \\
16 \cdot 4 \pm 2 \cdot 3(22) \\
0.65 \pm 0 \cdot 13(19)\end{array}$ & $\begin{array}{c}0.045 \pm 0.008(10) \\
10 \cdot 0 \pm 1 \cdot 9(9) \\
8 \cdot 8 \pm 0 \cdot 8(11) \\
0.51 \pm 0.13(11)\end{array}$ & $\begin{array}{c}0.084 \pm 0.013(15) \\
12 \cdot 4 \pm 1 \cdot 7 \text { (17) } \\
6 \cdot 5 \pm 0 \cdot 8(17) \\
0 \cdot 42 \pm 0.25^{*}(10)\end{array}$ \\
\hline $\begin{array}{lcc}\text { G-6-PD (U.) } & \ldots & \ldots \\
\text { 6-PGD (U.) } & \ldots & \ldots \\
\text { Acidic nuclear } & \text { protein } & \text { (mg.) }\end{array}$ & $\begin{array}{l}\cdots \\
\cdots \\
\cdots\end{array}$ & $\begin{array}{l}\cdots \\
\cdots \\
\cdots\end{array}$ & $\begin{array}{l}\cdots \\
\therefore \\
.\end{array}$ & $\begin{array}{l}\cdots \\
\cdots\end{array}$ & $\begin{array}{l}. \\
\cdots \\
\cdots\end{array}$ & $\begin{array}{l}. \\
\therefore \\
. .\end{array}$ & $\begin{array}{l}\cdots \\
\cdots \\
\cdots\end{array}$ & $\begin{array}{l}\cdots \\
\cdots \\
. .\end{array}$ & $\begin{array}{l}\cdots \\
\cdots\end{array}$ & $\begin{array}{l}\cdots \\
\cdots \\
\cdots\end{array}$ & \begin{tabular}{l|}
$\because$ \\
$\because$ \\
$\cdots$
\end{tabular} & $\begin{array}{l}0.59 \pm 0.16(20) \\
0.43 \pm 0.07(20) \\
3 \cdot 17 \pm 0.37(19)\end{array}$ & $\begin{array}{l}0.43 \pm 0.08(10) \\
0.21 \pm 0.05(9) \\
2.37 \pm 0.39(8)\end{array}$ & $\begin{array}{l}0.37 \pm 0.09(15) \\
0.13 \pm 0.04(15) \\
3.11 \pm 0.53(11)\end{array}$ \\
\hline
\end{tabular}




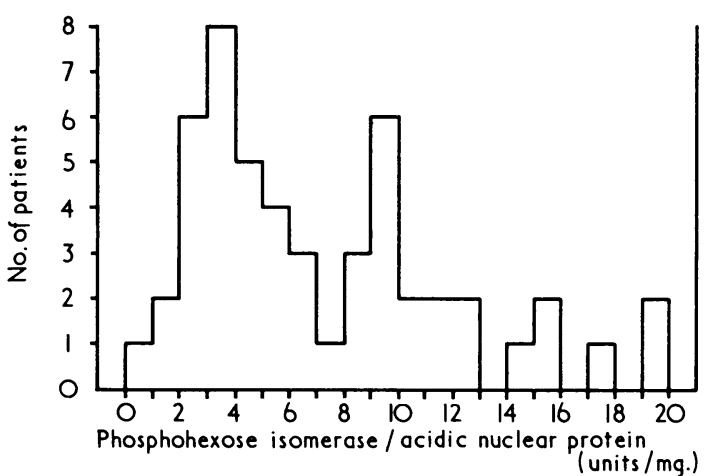

FIG. 3.-Distribution of values for phosphohexose isomerase activity per mg. acidic nuclear protein in 51 biopsies of human breast cancer.

two types of tumour-one in which this ratio is 7 or less, and the other in which it is more than 8.5. Of the 51 tumours analysed none have been found with intermediate values. This could have arisen in a number of ways-for example, bimodal distribution of either value alone, or of both independently; but the result could not, in fact, be explained in this way. It seems instead that the total population consists of two populations in which phosphohexose isomerase and acidic nuclear protein are correlated variables (Fig. 4) which can be separated on the basis of the bimodal distribution of phosphohexose isomerase/acidic nuclear protein. These variables were not correlated in the population as a whole.

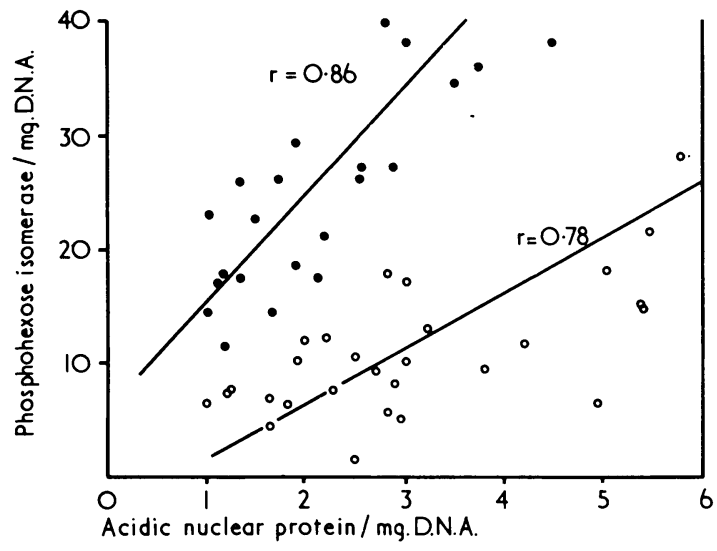

FIG. 4.-Correlations between phosphohexose isomerase activity and acidic nuclear protein content in tumours with ratios of phosphohexose isomerase to acidic nuclear protein $<7$ (open circles) and $>8.5$ (filled circles).

This ratio appears to have some bearing on prognosis, since the proportion of patients having tumours with high ratios decreased with increasing free period (Table II). It seems that patients with high ratios had a particularly poor prognosis. TABLE II.-Distribution of High and Low Phosphohexose Isomerase
(P.H.I.)/Acidic Nuclear Protein (A.N.P.) in Tumours from Patients with Different Postoperative Case Histories

\begin{tabular}{|c|c|c|c|c|c|c|c|c|}
\hline & \multirow{2}{*}{\multicolumn{2}{|c|}{ Free Period }} & & & & \multicolumn{2}{|c|}{ P.H.I./A.N.P. } & \multirow{2}{*}{$\begin{array}{c}\text { Percentage } \\
\text { with } \\
\text { High Ratio }\end{array}$} \\
\hline & & & & & & $<7.0$ & $\therefore 8.5$ & \\
\hline $\begin{array}{l}<2 \text { years }(14) \\
2-3 \text { years }(12) \\
>3 \text { years }(8) \ldots\end{array}$ & $\begin{array}{l}. \\
\cdots\end{array}$ & $\begin{array}{l}\cdots \\
\cdots\end{array}$ & $\begin{array}{l}\cdots \\
\cdots\end{array}$ & $\begin{array}{l}\ldots \\
\cdots\end{array}$ & $\begin{array}{l}\cdots \\
\cdots \\
\cdots\end{array}$ & $\begin{array}{l}8 \\
8 \\
8\end{array}$ & $\begin{array}{l}6 \\
4 \\
0\end{array}$ & $\begin{array}{r}43 \\
33 \\
0\end{array}$ \\
\hline
\end{tabular}

\section{Discussion}

The results were compatible with the view that tumours with high activities of phosphohexose isomerase, lactate $\underline{T}$ dehydrogenase, and 6-PGD are likely to recur sooner than those with low activities. The length of the free period $\stackrel{\mathbb{D}}{\Omega}$ apparently decreases with increasing divergence from the.. enzyme activity pattern of non-malignant breast tissue. It $\overrightarrow{\vec{F}}$ may be worth noting that this result depends on expressing $\stackrel{\text { ? }}{+}$ activities relative to D.N.A., and was not apparent on a wet $\bar{c}$ weight or protein basis. There are several possible explanations for these findings, which are mutually compatible.

(1) Enzyme activities could reflect the clinical stage or the $\stackrel{\mathbb{\Omega}}{\varrho}$ histological grade of the disease, which are known to be of $⿻$ some prognostic value (Bloom, 1962). Though our data indi- $\vec{\circ}$ cated that enzyme activities may be higher in later clinical stages none of the differences were significant. The data are $\vec{\omega}$ insufficient for deciding whether enzyme activities are of $\frac{\partial}{\partial}$ greater prognostic value than stage.

(2) Both enzyme activity and free period may be related to i growth rate of the tumour. It is reasonable to suppose that or rapidly growing tumours may recur sooner than those of slow $\exists$ growth, but in spontaneous mouse mammary tumours we have os been unable to show that the enzyme activities discussed here $\infty$ were related to growth rate (Smith and King, in preparation). The acidic nuclear protein content of rapidly growing tissues, $N$ however, is high (Stedman and Stedman, 1944; Mirsky and Pollister, 1946) and is related to growth rate in mammary tumours of rats and mice (Smith et al., 1966; Smith and ${ }^{\mathbb{D}}$ King, unpublished observations). If a similar relationship $\vec{\theta}$ exists in human tumours, our finding that high acidic nuclear $\bigcirc$ protein content was related to poor prognosis supports the idea that rapidly growing tumours recur rapidly.

(3) Another possibility is that enzyme activities are related to the hormone responsiveness of the tumours, since it has been shown that the probability of responsiveness of recur- $\mathbb{D}$ rent carcinoma of the breast is related to the clinical free $\overrightarrow{\vec{O}}$ period (McDonald, 1962). We have found low activities of $\frac{0}{3}$ both lactate dehydrogenase and phosphohexose isomerase in pregnancy-dependent mouse mammary tumours (unpublished), and Rees and Huggins (1960) reported similar findings for rat mammary tumours.

The peculiar distribution of phosphohexose isomerase/acidic nuclear protein may also be related to hormone respon- $\frac{\sigma}{3}$ siveness. This interpretation would agree with some results of ours which show that spontaneous pregnancy-dependent $\frac{O}{3}$ mammary tumours in BR6 mice had lower ratios than independent tumours irrespective of growth rate (Table III).

TABLE III.-Mean Values for Phosphohexose Isomerase and Acidic Nuclear Protein in BR6 Mouse Mammary Tumours

\begin{tabular}{|c|c|c|c|}
\hline & $\begin{array}{l}\text { P.H.I. } \\
\text { (U./mg. } \\
\text { D.N.A.) }\end{array}$ & $\begin{array}{l}\text { A.N.P. } \\
\text { (mg./mg. } \\
\text { D.N.A.) }\end{array}$ & P.H.I./A.N.P. \\
\hline $\begin{array}{l}\text { Pregnancy-dependent tumours } \\
\text { (rapid growth) } \\
\text { Pregnancy-independent tumours } \\
\text { (rapid growth) } \\
\text { Pregnancy-independent tumours } \\
\text { (slow growth).. } \ldots\end{array}$ & $\begin{array}{l}3 \cdot 9 \\
5 \cdot 6 \\
4 \cdot 7\end{array}$ & $\begin{array}{l}1.5 \\
1 \cdot 1 \\
0.9\end{array}$ & $\begin{array}{l}2 \cdot 6 \\
5 \cdot 1 \\
5 \cdot 2\end{array}$ \\
\hline
\end{tabular}

A bimodal distribution of phosphohexose isomerase:acidic $\stackrel{\mathbb{\Phi}}{\varrho}$ nuclear protein in human breast cancer could be explained if acidic nuclear protein were related to growth rate, and phos- 8 phohexose isomerase to both growth rate and hormone responsiveness. The use of acidic nuclear protein in the ratio would then act as a correction factor for growth rate, reveal- $\stackrel{?}{?}$ ing the difference in phosphohexose isomerase. This explanation would also account for the correlation of phosphohexose isomerase and acidic nuclear protein in the two groups of tumours. Further confirmation could be obtained only in a prospective clinical study, which we hope to arrange. 
Aisenberg, A. C. (1961). The REFERENCES A (1961). The Glycolysis and Respiration of Tumors. Allfrey, V. G., Littau, V. C., and Mirsky, A. E. (1964). Fournal of Cell Biology, 21, 213 .

Bloom, H. J. G. (1962). Acta; Unio Internationalis Contra Cancrum, 18, 842.

Bodansky, O. (1954). Cancer (Philadelphia), 7, 1191.

Burt

Lowry, O. H., Rosebrough, N. J., Farr, A. L., and Randall, R. J. (1951). Fournal of Biological Chemistry, 193, 265.
McDonald, I. (1962). Surgery. Gynecology and Obstetrics, 115, 215. Mirsky, A. E., and Pollister, A. W. (1946). Fournal of General Physiology, 30, 117

Rees, E. D., and Huggins, C. (1960). Cancer Research, 20, 963.

Shonk, C. E., and Boxer, G. E (1964). Cancer Research, 24, 709.

Shonk, C. E., Morris, H. P., and Boxer, G. E. (1965). Cancer Research, 25,671 .

Smith, J. A., King, R. J. B., Meggitt, B. F., and Allen, L. N. (1966). British fournal of Cancer, 20,335.

Stedman, E., and Stedman, E. (1944). Nature, 153, 500.

\section{Symptomatic Hypercalcaemia in Thyrotoxicosis}

\section{R. G. TWYCROSS, ${ }^{*}$ B.M., M.R.C.P. ; VINCENT MARKS, $†$ D.M., M.R.C.P., M.R.C.PATH.}

British Medical fournal, 1970, 2, 701-703

\begin{abstract}
ummary: In three patients with thyrotoxicosis and with symptomatic hypercalcaemia antithyroid therapy restored the plasma calcium concentration to normal, though initially in one case intravenous and oral neutral phosphate solution were required to curtail intractable vomiting.

Nine cases have been recorded in which the plasma calcium concentration returned to normal after antithyroid treatment was started; all but one became normocalcaemic within eight weeks. It is suggested that in hypercalcaemic thyrotoxicosis a second pathological condition should be considered only if the plasma calcium concentration fails to return to normal within eight weeks.
\end{abstract}

\section{Introduction}

In the past 15 years an increasing number of case reports linking thyrotoxicosis with hypercalcaemia have appeared in the literature. The combination, though forming only a small proportion of all patients with thyrotoxicosis, can result in a serious situation arising from acute and potentially fatal hypercalcaemic complications. We have recently studied three cases of hypercalcaemic thyrotoxicosis. In each case there was intractable vomiting, which in one case could be relieved only by lowering the plasma calcium concentration by intravenous inorganic phosphate infusion. In the other two cases treatment with carbimazole alone resulted in cessation of vomiting and lowered the plasma calcium level to within normal limits.

\section{Case 1}

A 33-year-old man gave a history of recurrent vomiting for 24 hours. Three weeks earlier he had felt nauseated for several days and had been transiently jaundiced. The relevant abnormal findings were hepatosplenomegaly, mild icterus, and a serum bilirubin concentration of $2.5 \mathrm{mg}$. $100 \mathrm{ml}$.; there was no evidence of haemolysis. Plasma calcium levels were consistently raised (Fig. 1).

Despite continued vomiting polyuria persisted with increasing dehydration. Further inquiry showed that he had lost over $20 \mathrm{lb}$. $(9 \mathrm{~kg}$.) in weight during the preceding six months. No direct thyroid function test was done at this time, but on the basis of the history and biochemical findings (Table I) a presumptive diagnosis of thyrotoxicosis was made. Treatment with carbimazole $10 \mathrm{mg}$. eight-hourly was instituted. The vomiting gradually stopped and the plasma calcium concentration returned to normal in three weeks. The blood urea concentration returned to normal levels (39 $\mathrm{mg}$. $/ 100 \mathrm{ml}$.), and creatinine clearance rose from 46 to $85 \mathrm{ml}$. per minute. Treatment with carbimazole was continued for 18 months.

A year and a half later the patient relapsed. He lost $8 \mathrm{lb}$. (3.6 kg.) in weight in three weeks and became mildly jaundiced: P.B.I. $9.8 \mu \mathrm{g} . / 100 \mathrm{ml}$., and bilirubin $2.1 \mathrm{mg} . / 100 \mathrm{ml}$. The plasma calcium and inorganic phosphate levels were both normal.

* Medical Registrar, Epsom District Hospital, Epsom, Surrey. t Consultant Chemical Pathologist, Epsom District Hospital, Epsom,
Surrey.

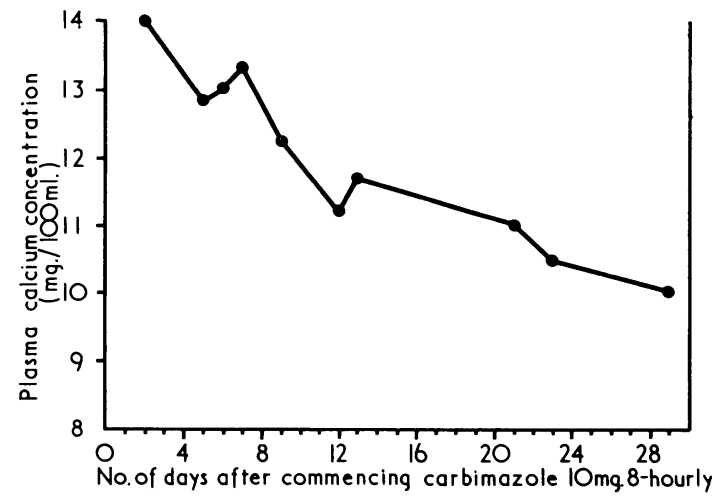

Fig. 1.-Case 1. Plasma calcium concentration during treatment.

TABLE I.-Initial Findings in Three Patients with Hypercalcaemic Thyrotoxicosis

\begin{tabular}{|c|c|c|c|c|}
\hline & Case 1 & Case 2 & Case 3 & $\begin{array}{l}\text { Mean } \\
\text { Normal } \pm 50\end{array}$ \\
\hline $\begin{array}{l}\text { Haemoglobin }(\mathrm{g} . / 100 \mathrm{ml}) \text {. . } \\
\text { Plasma urea concentration }\end{array}$ & & $12 \cdot 0$ & & $14 \cdot 8 \pm 0.9$ \\
\hline 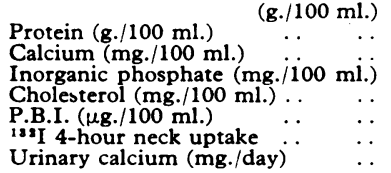 & $\begin{array}{r}180 \\
7 \cdot 0 \\
14 \cdot 0 \\
2 \cdot 9 \\
110 \\
\\
520\end{array}$ & $\begin{array}{c}59 \\
6 \cdot 0 \\
13 \cdot 9 \\
4 \cdot 5 \\
140 \\
20 \\
560\end{array}$ & $\begin{array}{l}24 \\
7.1 \\
13 \cdot 0 \\
3.5 \\
23 \\
87 \%\end{array}$ & $\begin{array}{c}\text { Range } 15-45 \\
6 \cdot 8 \pm 0 \cdot 3 \\
9 \cdot 7 \pm 0 \cdot 4 \\
4 \cdot 7 \pm 0 \cdot 4 \\
\text { Range } 150-320 \\
5 \cdot 0 \pm 0 \cdot 45 \\
\text { Range } 12-31 \% \\
300\end{array}$ \\
\hline
\end{tabular}

A further course of carbimazole was begun and an elective subtotal thyroidectomy was carried out some months later. The histology of the gland was compatible with partially treated thyrotoxicosis. Since operation (August 1967) the patient has kept well.

\section{Case 2}

A 22-year-old woman was admitted to hospital because of recurrent vomiting five weeks after she had developed typical thyrotoxic symptoms. The diagnosis was confirmed biochemically (Table I). The plasma calcium concentration was $13.9 \mathrm{mg} . / 100$ ml. Despite treatment with carbimazole, $10 \mathrm{mg}$. six-hourly, vomiting became more severe and the patient became increasingly dehydrated. This was corrected with intravenous fluid. Intravenous neutral phosphate curtailed the vomiting, but a week later this recurred and the plasma calcium concentration was 16 $\mathrm{mg} . / 100 \mathrm{ml}$. Further intravenous neutral phosphate, followed by oral supplements and cortisone acetate, led to a permanent cessation of vomiting and gradual restoration of normocalcaemia (Fig. 2).

Six weeks after starting carbimazole therapy oral phosphate and cortisone acetate were stopped without reappearance of hypercalcaemia. Two months later an elective subtotal thyroidectomy was performed. Histology was compatible with partially treated thyrotoxicosis. Since the operation (July 1967) the patient has remained well. 